DOI https://doi.org/10.18551/rjoas.2018-11.02

\title{
THE EFFECT OF BUSINESS STRATEGY AND ENVIRONMENTAL PERFORMANCE ON FIRM VALUE
}

\author{
Baihaqi Muchammad \\ Department of Accounting, Faculty of Economics and Business, \\ University of Airlangga, Surabaya, Indonesia \\ E-mail: qiqibaihaqi@outlook.com
}

\begin{abstract}
The purpose of this research is to know how the influence of business strategy and environmental performance to company value. Data from this research is obtained from PROPER assessment report listed on Indonesia Stock Exchange period 2015-2017. Data analysis using SPSS program. The results of this study found that business strategy has no effect on firm value and environmental performance have an effect on firm value. Limitations This study uses only 3 observation periods so that it is less able to generalize the findings.
\end{abstract}

\section{KEY WORDS}

Business strategy, environmental performance, firm value.

Competitive business conditions, demanding companies to develop competitive advantage strategies. Basically competitive advantage evolves from the value that the company is able to create for its buyers. Competitive advantages include positioning efforts to maximize the value of ability that differentiates it from competitors. Competitive advantage is defined as the excellence achieved continuously by implementing a strategy of achieving unique values that competitors do not have. It further said that the company has a competitive advantage if the company is able to create value that at the moment is not being done by either competitors or potential competitors and other companies are not able to imitate the advantages of this strategy (Ferdinand, 2003).

The higher the level of competition, the increasing complexity of the market and consumers who are becoming critical of the market, resulting in the company's operational activities need to be done professionally and aggressively. A competing strategy is a combination of goals that a company strives for with the wisdom or tool in which the company strives to achieve its goals. Competitive strategy aims to find a profitable position and can be maintained as well as possible against the pressure of competition. The choice of competitive strategy is based on competitive advantage that can be developed by the company. Competitive advantage will arise by having something that other competitors do not have. Hitt, et al. (2001) states to achieve strategic competitiveness and generate aboveaverage earnings, a firm analyzes its external environment, identifies opportunities within it, determines competent resources, and chooses an appropriate strategy to implement it to produce an output ( output) is good.

Miles and Snow (1978) divide four typologies of corporate strategy, namely prospector, defender, analyzer and reaction. Both interpret the prospector and defender as extreme different strategies. Prospector is a strategy that identifies and develops new products and exploits market opportunities, whereas defender is a strategy that tends to maintain market achieved and stable products with low cost leadership. Determination of strategy policy run by company either prospect strategy or defender will impact to company value in the future

Firm Value is the ability of a company to generate free cash flow at this time and in the future (Brigham and Ehrhardt, 2011). The value of the firm is also defined as the price that would be paid by the prospective buyer if the company is sold (Husnan, 2001) and can be reflected through the stock price of the company in the capital market. High Firm Value indicates that shareholder wealth is also high. The indicators of a good company one of them is having a high firm value. 
Companies that implement prospector strategies are companies that constantly do product development, create new products through research and development efforts, and expand market share of new products created (Amelia and Sudaryati, 2015). Companies that implement prospector strategies are constantly expanding market share by creating new products resulting from research and development conducted by all components of the company. The new product created is the result of management to absorb consumer preferences, so that new products can be well received by consumers.

Companies that implement prospector strategies have the advantage of experiencing an increase in profits from the opportunity to increase the sales price of new products created due to the lack of existing competitors in similar products. The existence of high sales price levels and the lack of existing competitors, then companies that implement prospector strategies will have an opportunity to increase their company's profit (Aulia, 2010). The possibility of obtaining higher profits compared to competitors will have an impact on the increasing perceptions of capital market investors on companies that implement prospector strategies. Increased perceptions of capital market investors on companies that implement prospector strategy is shown from the increase in stock price of the company. The increase in stock price of the company, will be continued by the increase of company value.

In addition, companies that implement defender strategies are companies that keep their market niche (Habbe and Hartono, 2001). In addition, companies that implement defender strategies will strive to perform a minimum cost strategy to improve the company's earnings performance. Companies that are able to minimize production costs will have an impact on the increase in corporate profits. The strategy of minimizing costs is done by firms when firms are unable to execute extensification strategies and intensify their products.

The opportunity to create an increase in corporate profits will be appreciated positively by capital market investors by purchasing large amounts of shares in companies that implement defender strategies. Investors will invest heavily in companies with defender strategies in hopes of gaining higher capital gain through the efforts of defender companies to continue to provide dividends to investors. A positive appreciation from investors will have an impact on the rising Firm Value of the perception of capital market investors.

In addition to business strategy, companies must be able to create a strategy that comes from the needs of external stakeholders. An environment-based strategy is one of the needs that companies must run to meet the expectations of stakeholders (Gray et al., 1997). To create an appropriate environmental strategy, the company can perform a good environmental performance, so the opportunity to get a positive appreciation from stakeholders can be maintained.The large number of investors who care about environmental conditions encourage companies to constantly improve their environmental performance in order to attract investors or stakeholders to invest their shares so as to increase the value of the company. Mementingkan role of an organization (company) with the surrounding community and must gain trust in the eyes of stakeholders by conducting high environmental activities. It is believed that a company with high environmental performance will influence the surrounding community and investors in accordance with the theory of legitimacy.

Based on the theory of triple bottom line that was discovered by Elkington (1970), the company is not merely oriented to seek profit (profit) alone. However, companies must be able to meet the 3P elements as the company's goal, namely: profit, people, and the planet. Elements of the planet according to Elkington (1970) is an effort to maintain the company's environmental sustainability, so it can provide sustainable benefits for the company in the future. The company's efforts to preserve the environment are an effort to defend the resources of companies that are sourced from nature

\section{LITERARTURE REVIEW}

The Theory of Triple Bottom Line (TBL or 3BL). Or also 3P - People, Planet and Profit. In short, the three are pillars that measure the value of a company's success with three criteria: economic, environmental, and social (Elkington, 1988). In fact, this approach has 
been widely used since the beginning of 2007 as the development of a full cost accounting approach that is widely used by public sector companies. In private sector companies, the implementation of Social Responsibility (CSR) is one form of TBL implementation. The concept of TBL implies that the company should prioritize the interests of stakeholders (all parties involved and affected by the activities of the company) rather than the interests of shareholders.

People emphasize the importance of a company's business practices that support the interests of the workforce. More specifically this concept protects the interests of labor by opposing explorations that employ minors, reasonable wage payments, safe working environments and tolerable working hours. Not only that, the concept also asks the company to pay attention to health and education for the workforce. Planet means managing well the use of energy especially on non-renewable natural resources. Reducing waste products and recycling into safe waste for the environment, reducing $\mathrm{CO} 2$ emissions or energy use, is a common practice by companies that have adopted this concept.

Introduction to the concept of an organization's growing corporate environment in line with the development of a systems approach in management, has changed the way managers and management theorists view organizations, especially about how a company's organization can achieve its goals effectively. The occurrence of an orientation shift in the business world from shareholders to stakeholders has been cited as the cause of the emergence of corporate social responsibility issues. Stakeholders are people or groups of people who can influence or be influenced by various decisions, policies, or company operations. According to Jones in Solihin (2009) explains that the shareholders are divided into two categories:

a. Inside stakeholders, consists of persons who have interests and demands on company resources and are within the organization of the company. Parties included in the category of internal stakeholders are shareholders, managers and employees.

b. Outside stakeholders, consisting of persons or parties who are not the owners of the company, not the corporate leaders, nor the employees of the company, but have an interest in the company and are influenced by decisions and actions taken by the company. The parties included in the category of outside stakeholders are customers, suppliers, government, local communities, and society in general.

Stakeholder theory provides a firm view as an nexus of contract by incorporating investors and investors as corporate stakeholders. This stakeholder theory proposed by Cornell and Shapiro (1987) supplemented the findings of Titman (1984) in Hatta (2002). Meanwhile, according to Freeman et al. (2004) in Wibowo (2008) argued that the theory of stakeholders began with the assumption of value (value) explicitly and undeniably is part of business activities.

The stakeholder approach enables the organization to choose to respond to the many demands made by stakeholders, that is, any group within the external environment of the organization that is affected by the organization's actions and decisions. According to this approach, an organization will strive to meet the environmental demands of groups such as employees, suppliers, and investors and society (Robbins and Coulter, 1999) in Januarti and Apriyanti (2005).

Strategy is a competing tool that needs to be owned by companies where in its application requires planning, coordination, supervision and evaluation of a strong and accurate so as to create competitive advantage for the company. Application of strategy especially at business level is a job that require big challenge because often the implementation of this business strategy is not able to balance the achievement of expected target. Implementation of business strategy is an important task for managerial in achieving organizational success. Managerial duties in implementing and implementing these strategy choices require assessments that will develop the needs of organizational capability and targeted target achievement (Thompson and Strickland, 2003).

The right strategy choice will create superior performance for the organization. This choice of strategy becomes a necessary part of creating value for consumers and generating competitive advantage for the company (Porter, 1980). The strategy applied must be in 
accordance with the core competencies that are owned and the external conditions of the company. Porter explains that there are three strategies that can create competitive advantage for the company that is the overall low cost leadership, differentiation and focus. Balsam et al. (2011) states that the strategy measurement uses four indicators: General Expens / Net Sales, Net Sales / Cost of Goods Sold, Net Sales / Capital Expense, and Total Assets/Number of Employees.

Environmental performance is measured from company achievement following PROPER program. The program is one of the efforts made by the Ministry of Environment $(\mathrm{KLH})$ to encourage corporate governance in environmental management through information instruments (Rakhiemah and Agustia, 2009).

Firm Value is the valuation or price given by market participants on the overall performance of the company. Firm Value can show the performance of management in managing the company's assets (Amanti and Venusita, 2012). The value of the company can be seen from the stock price of the company that is willing to be purchased by investors / potential investors. Maximizing the value of the company is one of the goals of the establishment of a company (Agustina, 2013, Amanti and Venusita, 2012). Increased Firm Value will be seen from the increase of stock price of the company. Increased share price will then improve the welfare of the company's stakeholders (Nurlela, 2008). This study uses Tobin's $Q$ ratio to calculate the company's value.

\section{MODEL AND HYPOTHESES DEVELOPMENT}

Business strategy determines the success of an organization. Strategies are created with the aim of enhancing Firm Value and creating competitive advantage. Companies that implement one strategy have specific ways to increase the value of the company. Companies that implement prospector strategies have the advantage of experiencing an increase in profits from the opportunity to increase the sales price of new products created due to the lack of existing competitors in similar products. The existence of high sales price levels and the lack of existing competitors, then companies that implement prospector strategy will have an opportunity to increase their company's profit.

The existence of these strategies has the effect of hope for prospective companies to increase the value of the company. Companies that are able to minimize production costs will have an impact on the increase in corporate profits. The strategy of minimizing costs is done by firms when firms are unable to execute extensification strategies and intensify their products. The opportunity to create an increase in corporate profits will be appreciated positively by capital market investors by purchasing large amounts of shares in companies that implement defender strategies. Based on the explanation, the first hypothesis can be formulated as follows:

$\mathrm{H} 1$ : The company's business strategy affects the firm's value.

To create an appropriate environmental strategy, the company can perform a good environmental performance, so the opportunity to get a positive appreciation from stakeholders can be maintained. The large number of investors who care about environmental conditions encourage companies to constantly improve their environmental performance in order to attract investors or stakeholders to invest their shares so as to increase the value of the company. Mementingkan role of an organization (company) with the surrounding community and must gain trust in the eyes of stakeholders by conducting high environmental activities. Capital market investors believe that companies that have good environmental performance will convey information related to environmental management as well.

This will be useful for investors to explore information related to the activities undertaken by the company. The widespread in the delivery of such information will have an impact on the lower costs incurred by investors to seek additional information related to the company's operational activities. The decrease in the cost incurred by capital market investors will encourage capital market investors to accumulate more shares of the company, 
thus increasing the company's stock price. An increase in stock price will have an impact on the company's rising value.

Based on the explanation, the second hypothesis can be formulated as follows:

$\mathrm{H} 2$ : Environmental performance affects the firm's value.

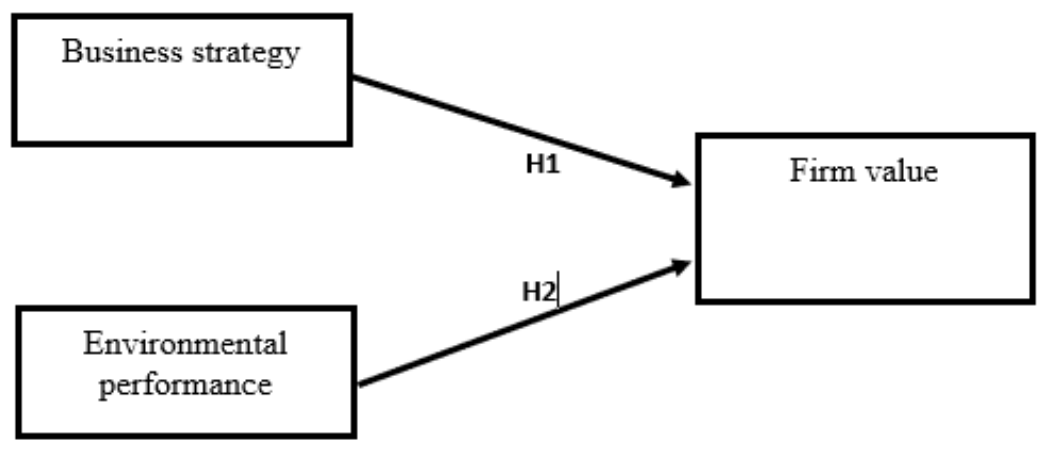

Figure 1 - Research Model

\section{METHODS OF RESEARCH}

Sample selection was obtained by selecting 177 companies. With years of research in 2015,2016 and 2017.Population in this study are companies listed on the Indonesia Stock Exchange and PROPER. The sample of this research is taken by using purposive sampling technique which is manufacturing company, mine and plantation which listed in Indonesia Stock Exchange and that follow Program of Rating of Company Performance in Environmental Management (PROPER) in 2015-2017 and have published annual report ). Sample selection is done by using purposive sampling technique with judgment sampling, that is a technique of determining sample by using certain consideration (Anshori and Iswati, 2009: 105).

Research conducted by asdemir and triphaty (2013) suggests that the market places a positive value on companies that successfully pursue either cost leadership or differentiation strategies; In addition the market places a higher value on firms that pursue differentiation strategies compared to cost leadership strategies. This study uses Tobin $Q$ as a measure of market perception. With Tobin's retreat on relevant control variables and proxies for differentiation and cost leadership strategies, this paper evaluates the relationship between market perception and corporate strategy.

Al-Najjar and Anfimiadou (2012) examine environmental policies and firm values. object research company in the UK with observation years 1999 to 2008. With the results of research Acceptance of environmental efficiency award has a relationship between environmental efficiency and value of the company provide evidence to investors that an environmentally efficient company can generate higher future profits.In addition, environmental standards with the company's business processes is one of the company's key business strategies involved in environmental strategy. Thus, these companies are in a position to improve efficiency and effectiveness as their processes operate in line with changes in environmental conditions. As mentioned earlier, by optimizing their systems, businesses will save time, cost and reduce risk and therefore increase the value of the company.

Operational Definition and Variable Measurement Independent Variables. The business strategy in this study follows the opinion of Ballsam et al, 2011 using the following indicators:

$$
\text { BS } 1=\frac{\text { General Expense }}{\text { Net Sales }} \text { BS } 2=\frac{\text { Net Sales }}{\text { COGS }} \text { BS } 3=\frac{\text { General Expense }}{\text { Cost of Capital }} \text { BS } 4=\frac{\text { Total Asset }}{\text { Number of Employees }}
$$


Whereas environmental performance using the PROPER rating system includes a company rating in five colors: Gold: Very Very Good Skor $=5$, Green: Very Good Skor $=4$, Blue: Good Skor $=3$, Red: Bad Skor $=2$, Black: Very Bad Skor $=1$.

Table 1 - Ranking Description

\begin{tabular}{|l|l|}
\hline Ranking & Description \\
\hline Gold & $\begin{array}{l}\text { It has consistently demonstrated environmental excellence in the production process and / or services, } \\
\text { conducting ethical and accountable business; }\end{array}$ \\
\hline Green & $\begin{array}{l}\text { Has been managing the environment more than required under the rules (beyondcompliance) through } \\
\text { the implementation of environmental management system, efficient utilization of resources through 4R } \\
\text { efforts (Reduce, Reuse, Recycle and Recovery) }\end{array}$ \\
\hline Blue & $\begin{array}{l}\text { Has undertaken the required environmental management efforts in accordance with the provisions } \\
\text { and or laws and regulations; }\end{array}$ \\
\hline Red & $\begin{array}{l}\text { Environmental management does not comply with the requirements as regulated in the legislation; } \\
\text { Black }\end{array}$ \\
\hline
\end{tabular}

Source: Proper Report, 2017.

Dependent Variables. In this study the measurement of firm value using the ratio of Tobin's $Q$ to calculate the value of the company. Tobin's $Q$ ratio can reflect the value of the firm, because it incorporates the company's debt and equity in the calculation (Agustina, 2013).

$$
\mathrm{Q}=\frac{M V E+D}{B V E+D}
$$

Where: $\mathrm{Q}=$ Firm value; $\mathrm{MVE}=$ Market Value Equity; BVE $=$ Book Value Equity; $\mathrm{D}=$ The book value of total debt.

If a firm has a Tobin's $Q$ ratio of more than 1, the profits generated by the company's assets exceed the value of the investment issued to acquire the asset (Agustina, 2013; Amanti and Venusita, 2012).

\section{RESULTS AND DISCUSSION}

The result of analysis from the influence of business strategy and environmental performance to company value is presented in the following table.

Table 2 - Variables Description

\begin{tabular}{llllll}
\hline Variable & $\mathrm{N}$ & Minimum & Maximum & Mean & Std. Deviation \\
\hline $\mathrm{NP}$ & 177 & .338528 & 2.053086 & 1.06924654 & .321154080 \\
$\mathrm{SB}$ & 177 & 0 & 1 & .1 & .303 \\
$\mathrm{KL}$ & 177 & 2 & 5 & 3.10 & .441 \\
\hline
\end{tabular}

Table 2 explained the total data obtained for the period 2015-2017 obtained 177 observation data.

Based on the table it is known that the Company Value (NP) has the lowest value of 0.338528 at PT Indospring Tbk and the highest value of 2.053086 at PT Semen Gresik TBK Average value of the company owned by all sample companies of 1.06924654 standard deviation of 0,321154080 . This shows the level of data spread of the company value has a variation rate of $30.04 \%$. Due to the level of variation $<100 \%$ it can be concluded that the data is homogeneous, which means the characteristics of sample data each company has a relatively equal amount.

Business Strategy (SB) has the lowest value of 0 at PT BUDI Strach and the highest value of 1 in PT Kabelindo Murni TBK Average business strategy owned by all sample companies of 0.1 with standard deviation of 0.303 . This shows the level of data distribution business strategy has a variation rate of $303 \%$. Due to the level of variation> $100 \%$ it can be concluded that the data is heterogeneous, which means the sample data characteristics of each company has a relatively different amount. Based on the table it is known that 
Environmental Performance (KL) has the lowest value of 2 on PT Indofood Sukses Makmur TBK and PT Cable Wire TBK while the highest value of 5 in PT Aneka Tambang TBK and PT Bukit Asam TBK Average environmental performance owned by all companies sample of 3.10 with standard deviation of 0.441 . This shows the level of data distribution of environmental performance has a level of variation of $14.22 \%$ means that the existing data is homogeneous or has the characteristics of sample data that tend to be the same for all companies.

Table 3 - Pearson Correlation

\begin{tabular}{llll}
\hline & $\mathrm{NP}$ & $\mathrm{SB}$ & $\mathrm{KL}$ \\
\hline $\mathrm{NP}$ & 1 & & \\
$\mathrm{SB}$ & -1.07 & 1 & 1 \\
$\mathrm{KL}$ & 0.198 & -1.63 & \\
& $(0.674)$ & $(0,120)$ & \\
\hline
\end{tabular}

Table 4 - Variables

\begin{tabular}{lll}
\hline Variable & Model -1 & P-Value \\
\hline SB & Conf & 0.311 \\
KL & 0.80 & 0.14 \\
Consant & 0.55 & - \\
\hline
\end{tabular}

Based on the results of research shown in table 3 it can be concluded that the variable, business strategy (SB) does not affect the company value (NP) this can be seen based on the value $p$-valuesebesar 0.311 where the value $<0.05$. It can be concluded that the results are not in line with the hypothesis 1 (one) ie business strategy variables affect the value of the company.

While for the environmental performance $(\mathrm{KL})$ variable has a positive effect on Company Value (NP) this is indicated from the p-value value of 0.014 where the value is $<0.5$. It can be concluded that the hypothesis 2 (one) namely the variable of Environmental Performance has an effect on the firm value.

\section{CONCLUSION}

The result of hypothesis testing 1 states that business strategy has no effect on firm value. The results show that the strategy run by the company is not able to encourage capital market investors to be more oriented in investing. The capital market investor considers that the forms of strategy undertaken by the company have their own advantages for capital market investors, where companies will look for tactical ways of improving corporate earnings performance. This resulted in the lack of attention of capital market investors in viewing the company's business strategy as a step in making investments. The results of this study are in line with Henderson and Hughes (2010). Hypothesis 2 states that environmental performance has an effect on the value of the company, where to create an appropriate environmental strategy, the company can run a good environmental performance, so the opportunity to get positive appreciation from stakeholders can be maintained. Many investors who care about environmental conditions encourage companies to constantly improving its environmental performance in order to attract investors or stakeholders to invest their shares so as to increase the value of the company. Mementingkan role of an organization (company) with the surrounding community and must gain trust in the eyes of stakeholders by conducting high environmental activities. Capital market investors believe that companies that have good environmental performance will convey information related to environmental management as well.

This will be useful for investors to explore information related to the activities undertaken by the company. The widespread in the delivery of such information will have an impact on the lower costs incurred by investors to seek additional information related to the company's operational activities. The decrease in the cost incurred by capital market 
investors will encourage capital market investors to accumulate more shares of the company, so that the stock price increases. The increase in stock price will have an impact on the increase of company value. This research is in line with research conducted asdemir et al (2013).

This study aims to find out how the business strategy and environmental performance can affect the value of the company. In this study we found out that business strategy has no effect on firm value. This is because corporate strategy can not describe the value of the company as a whole. While for our environmental research performance resulted in an influence on firm value. Our findings show that the company's environmental performance can reflect the full value of the company.

Limitations in this study were to use only three periods of company observation as research samples, thus less bias generalize the results of these findings. Therefore, further research can use more than three-year observation periods to make the results more relevant.

\section{REFERENCES}

1. Abebe, M., \& Cha, W. (2018). The effect of firm strategic orientation on corporate philanthropic engagement. Management Decision, 56(3), 515-533.

2. Amo-Yartey, C., \& Abor, J. (2013). Corporate financial policies in emerging markets: the role of financial market development. American Journal of Business, 28(2), 123-146.

3. Anwar, J., \& Hasnu, S. A. F. (2017). Strategic patterns and firm performance: comparing consistent, flexible and reactor strategies. Journal of Organizational Change Management, 30(7), 1015-1029.

4. Asdemir, O., Fernando, G. D., \& Tripathy, A. (2013). Market perception of firm strategy. Managerial finance, 39(2), 90-115.

5. Boamah, N. A. (2017). The global financial market integration of selected emerging markets. International Journal of Emerging Markets, 12(4), 683-707.

6. Canavan, D., Sharkey Scott, P., \& Mangematin, V. (2013). Creative professional service firms: aligning strategy and talent. Journal of Business Strategy, 34(3), 24-32.

7. Castellano, N. G., \& Del Gobbo, R. (2018). Strategic mapping: relationships that count. Management Decision, 56(4), 908-921.

8. Chatmi, A., \& Elasri, K. (2017). Competition among vortex firms: Marketing, R\&D or pricing strategy. The Journal of High Technology Management Research, 28(1), 29-46.

9. Chuang, Y. T., Dahlin, K. B., Thomson, K., Lai, Y. C., \& Yang, C. C. (2015). Multimarket contact, strategic alliances, and firm performance. Journal of Management.

10. Chuang, Y. T., \& Thomson, K. (2017). Maneuvering multimarket competition: The effects of multimarket contact and strategic alliances on performance of single-market firms. Strategic Organization, 15(3), 390-409.

11. Chung, H. F., \& Kuo, T. (2018). When and how managerial ties matter in international competitive strategy, export financial and strategic performance framework: A standardized or customized approach?. European Journal of Marketing, 52(1/2), 260278.

12. Cuevas-Rodriguez, G., Guerrero-Villegas, J., \& Valle-Cabrera, R. (2016). Corporate governance changes, firm strategy and compensation mechanisms in a privatization context. Journal of Organizational Change Management, 29(2), 199-221.

13. Currim, I. S., Lim, J., \& Zhang, Y. (2016). Commitment to marketing spending through recessions: Better or worse stock market returns?. European Journal of Marketing, 50(12), 2134-2161.

14. Fernando, G. D., Schneible Jr, R. A., \& Tripathy, A. (2016). Firm strategy and market reaction to earnings. Advances in Accounting, 33, 20-34.

15. Filatotchev, I., Bell, R. G., \& Rasheed, A. A. (2016). Globalization of Capital Markets: Implications for Firm Strategies. Journal of International Management, 22(3), 211-221. 
16. Gomes, R. M. D. A. B., Paula, F. D. O., \& Macedo-Soares, T. D. L. V. A. D. (2017). Strategic alliances of shopping centers in Brazil: network perspective. Management Research: Journal of the Iberoamerican Academy of Management, 15(2), 167-186.

17. Gossé, J. B., \& Plihon, D. (2014). The future of financial markets and regulation: what strategy for Europe?. Foresight, 16(2), 95-108.

18. Gyan, A. K., Brahmana, R., \& Bakri, A. K. (2017). Diversification strategy, efficiency, and firm performance: Insight from emerging market. Research in International Business and Finance, 42, 1103-1114.

19. Hao, S., \& Song, M. (2016). Technology-driven strategy and firm performance: Are strategic capabilities missing links?. Journal of Business Research, 69(2), 751-759.

20. Kindström, D., Ottosson, M., \& Carlborg, P. (2017). Unraveling firm-level activities for shaping markets. Industrial Marketing Management.

21. Lee, C. C. (2013). Business service market share, international operation strategy and performance. Baltic Journal of Management, 8(4), 463-485.

22. Leitner, K. H. (2014). Strategy formation in the innovation and market domain: emergent or deliberate?. Journal of Strategy and Management, 7(4), 354-375.

23. Luo, Y., \& Bu, J. (2017). Contextualizing international strategy by emerging market firms: A composition-based approach. Journal of World Business.

24. Mallon, M. R. (2017). Getting buy-in: financial stakeholders' commitment to strategic transformation. Management Research: Journal of the Iberoamerican Academy of Management, 15(2), 227-243.

25. Martynov, A. (2015). Alliance Portfolios And Firm Performance: The Moderating Role Of Firm Strategy And Resources. In Academy of Management Proceedings (Vol. 2015, No. 1, p. 11253). Briarcliff Manor, NY 10510: Academy of Management.

26. Navarro, A., Sicilia, M., \& Delgado-Ballester, E. (2009). Integrated marketing communications: Effects of advertising-sponsorship strategic consistency. EuroMed Journal of Business, 4(3), 223-236.

27. Pan, Y. (2017). Strategic motives, institutional environments, and firm's FDI ownership. Multinational Business Review, 25(4), 307-327.

28. Rodríguez-Escobar, J. A., \& González-Benito, J. (2017). The effect of strategic alignment on purchasing management. Management Research Review, 40(11), 1175-1200.

29. Sibony, O., Lovallo, D., \& Powell, T. C. (2017). Behavioral strategy and the strategic decision architecture of the firm. California Management Review, 59(3), 5-21.

30. Yarbrough Jr, E., Abebe, M., \& Dadanlar, H. (2017). Board political experience and firm internationalization strategy: A resource dependence perspective. Journal of Strategy and Management, 10(4), 401-416.

31. Yi, Y., Gu, M., \& Wei, Z. (2017). Bottom-up learning, strategic flexibility and strategic change. Journal of Organizational Change Management, 30(2), 161-183.

32. Yoon, J., \& Moon, J. (2017). The moderating effect of buyer purchasing strategy on the relationship between supplier transaction-specific investment and supplier firm performance. Journal of Business Research.

33. W. Ridge, J., Kern, D., \& A. White, M. (2014). The influence of managerial myopia on firm strategy. Management Decision, 52(3), 602-623. 